\title{
ハムスター舌背の形態学的研究 —一特に解剖名に関して—
}

藤田浄秀・大村 進・鈴木信治 小田島哲世*・大谷隆俊

\section{Morphological study on lingual dorsum of the hamster, with special consideration to anatomical terms}

\author{
Kiyohide Fujita - Susumu Ohmura - Nobuharu Suzuki \\ Tetsuyo Odajima* * Takatoshi OHtani
}

\section{はじめに}

八ムスター (Mesocricetus auratus)の槙整以外は困難 と考えられていた口腔粘膜癌の実験的形成は，八ムスタ 一口腔の種々の部位に 9,10-dimethyl-1,2-benzanthraceneのアセトン溶液を整布することにより, 舌癌・口蓋 粘膜癌・歯肉癌などが，短期間に，しかも高率に形成す ることが可能となった

最近われわれは，八ムスター口腔粘膜癌形成過程の走 查電顕的研究を行っており，舌側縁中 $1 / 3$ 部における舌 癌形成過程に関してはすでに報告した ${ }^{12)}$ ，次いで舌背部 における舌癌形成過程 ${ }^{13}$ や雪肉癌の形成過程 ${ }^{14}$ ， 口蓋粘 瞙癌の形成過程(5)などを検討している。

しかし，八ムスター口腔粘膜の形態学的研究は活とん どなされて拉らず，したがって部位によっては解剖名が 明確に命名されて扣らず，また解剖名の混乱もあると思 われる。

われわれが今後に報告を予定している一連の八ムスタ

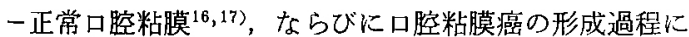
関する走查電顕的研究 ${ }^{13 \sim 15)}$ のためには，関係のある部位 の口腔粘膜の解剖名を明確にしておくことが必要であ る。

今回は，舌背部における舌癌形成過程の走查電顕的研

横浜市立大学医学部口腔外科学教窒

（主任：大谷隆俊教授）

* 東日本学園大学蔽学部口腔病理学教窒 （主任：奥山富三教授）

Department of Oral Surgery, School of Medicine, Yokohama City University (Chief: Prof. Takatoshi Ohtani)

* Department of Oral Pathology, School of Dentistry, Higashi Nippon Gakuen University (Chief: Prof. Tomizoh Okuyama) 受付日：昭和57年 1 月 25 日

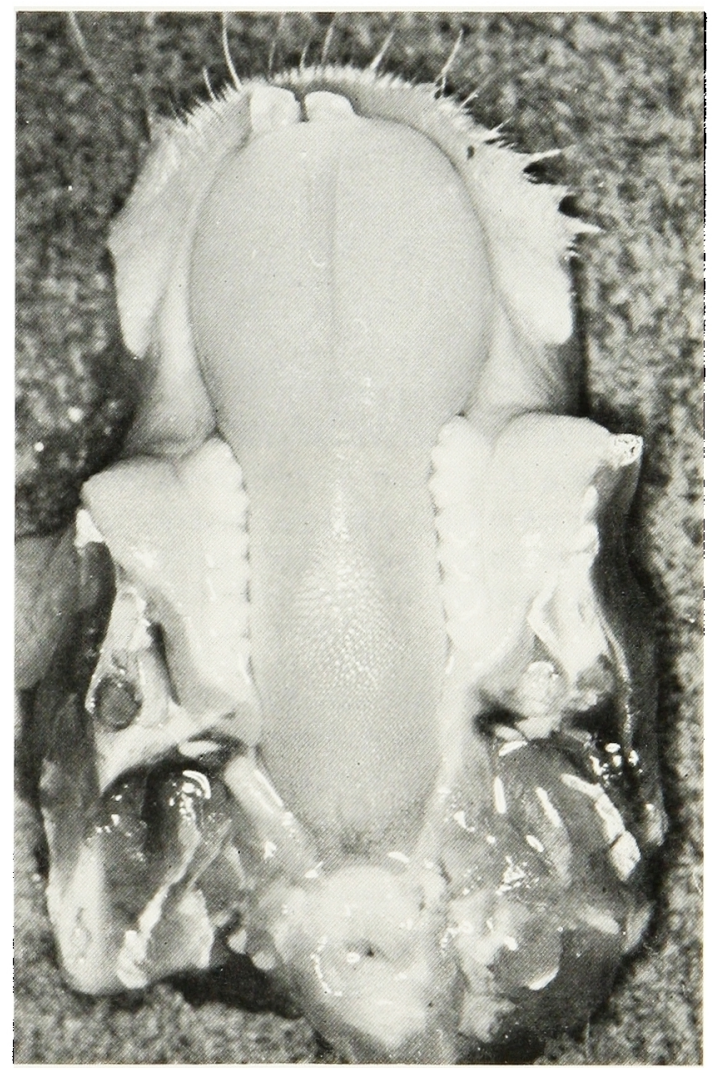

写真 1 八ムスター舌背の肉眼所見

究133の基礎資料とするために，正常ハムスター舌背部の 走查電顕的钼察結果 ${ }^{16)}$ を報告するにさきだち，八ムスタ 一の舌背，特に舌乳頭の解剖名に関して，われわれの見 解を述べる。

実験材料ならびに方法

生後約 $5 \sim 8$ 週路のゴールデンハムスター（Mesocri- 


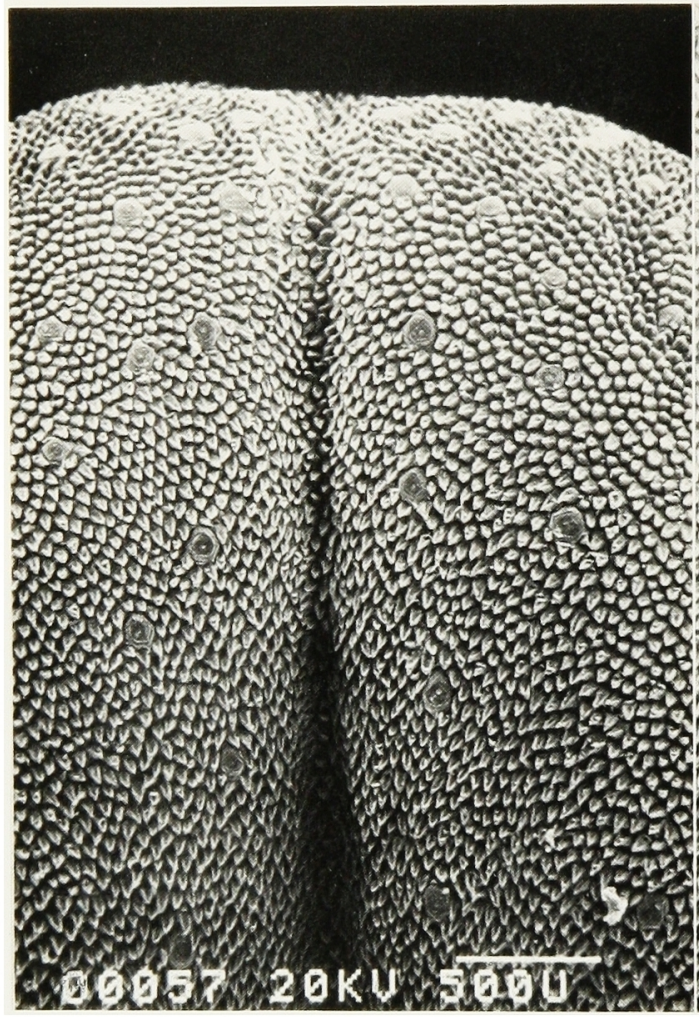

写真 2 八ムスタ一舌背の走查電顕所見

舌前 $1 / 3$ 部, 特に舌尖部付近. 舌正中啮が認められ る。小さな糸状乳頭に混在して，散在性に，円形の 茸状乳頍が比校的多く認められる。

cetus auratus) 20 匹をェーテル麻酔下に屠殺し，3匹 は下顎摘出後に, ニュン $\mathrm{F}_{2}$ とィディカルニッュール C にて写真を撮影し，10匹は10\%中性ホルマリンにて固定 後に光影用組織標本 (H-E 染色) とし, 残り 7 匹は舌摘 出後に生食で洗浄し，ただらに $1.5 \%$ グルタールアルデ ヒド単独固定を行ったのち，上昇エタノールで脱水し， 酢酸イソフミルに置換後，炭酸ガス臨界点乾燥を行い， 観察面に全イオンスパッタを施し，日立 S-450型走查電 顕にて観察した

\section{観 察 結 果}

\section{ハムスター舌背の肉眼所見}

ハムスターの舌背は，舌背㑑より钼察すると，前後 (rostral-caudal) に長く，歯隙 ${ }^{18}$ (diastema) に相当する 部分では幅広いが，巨目州に相当する部分では网側より压 排されたように幅が狄くなっており，さらに自幽より後 方に相当寸る部分では䍀び幅がやや広くなっている（写 真 1 )

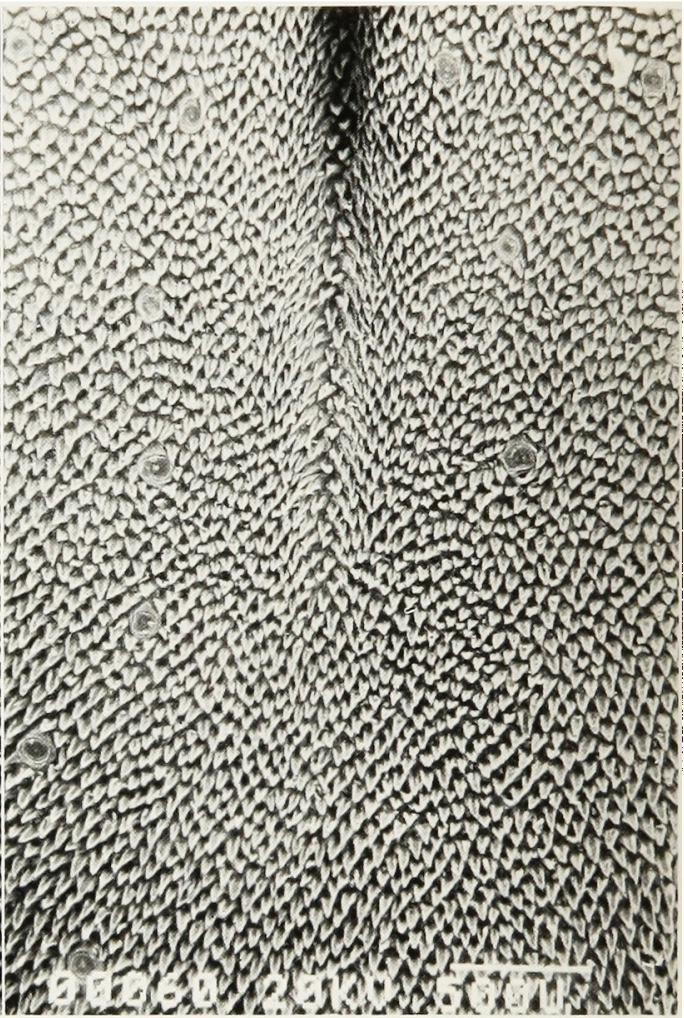

写真 3 八厶八夕一舌背の走查電影所見

舌前 $1 / 3$ 部と舌中 $1 / 3$ 部との境界部付近。舌正中溝 は，舌中 $1 / 3$ 部では認められなくなる，丠状乳頭は 数が少なくなっている。

舌前 $1 / 3$ 部の舌背正中に明らかな艂（suicus, furrow） が認められるが，舌中 $1 / 3$ 部では認められなくなる。

舌中 $1 / 3$ 部之舌後 $1 / 3$ 部之の境界付近の舌背正中に, やや白くみえる隆起が認められる，この隆起は，明らか な境界なしに次第に舌後 $1 / 3$ 部に移行している。

䐅頭蓋より $2 \sim 3 \mathrm{~mm}$ 前方 (rostral) の舌正中線上K， 1 個の楕円形の榄造物が認められる。

舌背表面は，舌前 $1 / 3$ 部ならびに舌中 $1 / 3$ 部において は粗槛にみえる、乙かし，乳頭は肉眼的には識別できな い，ところどころに赤い斑点状の棈造物も諗められる。

舌背隆起部ならびに舌後 $1 / 3$ 部においては，系状の稤 頭が肉腿的に識別できる。しかし，舌後 $1 / 3$ 部の最後部 付近，すなわち喉頭蓋より $2 \sim 3 \mathrm{~mm}$ の範囲には，糸状 の乳頭は認められない

\section{ハムスタ一舌背の走查電影的所見}

舌前 $1 / 3$ 部ならびに舌中 $1 / 3$ 部に拈いてては，比較的小 さい，いわゆる円錘状 (cone-shaped) の糸状の乳頭が歌 められる(写真 2，3)。乳頭の头端は後方 (caudal) に向 いている，しかし，舌尖部付近で形態が小さくまた舌 


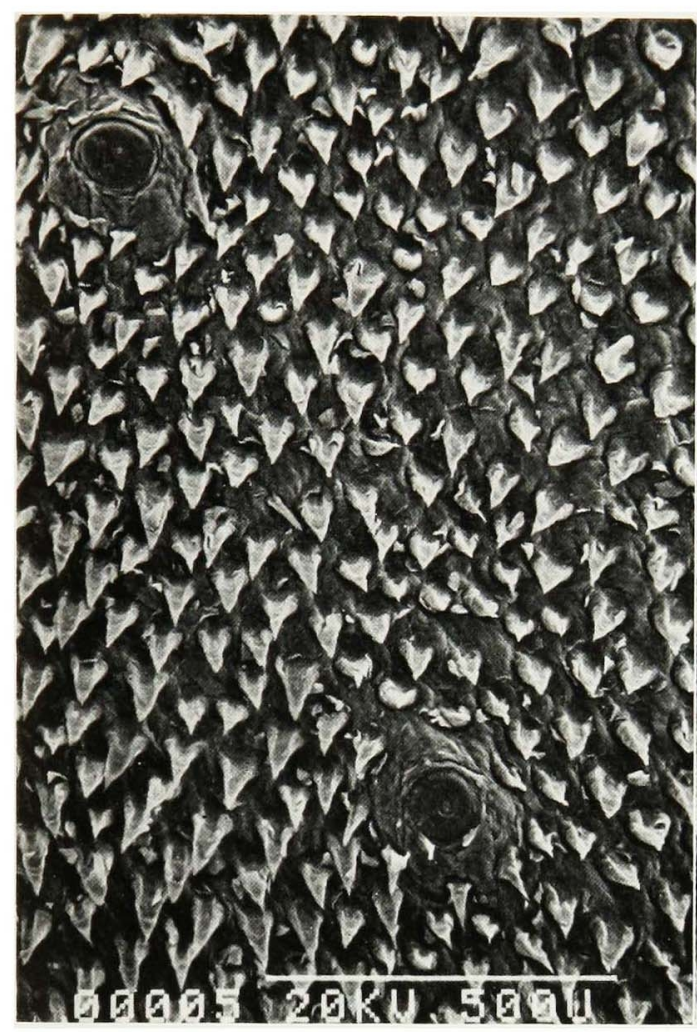

写真 4 ハムスター舌背の走查電影所見 舌中 $1 / 3$ 部の扰大.
辺縁部においては，乳頭の尖端は必ずしも明確に後方に 向いていない，系状の乳頭に混在して，散在性に茸状の 乳頭が認められる（写真 2，3）。肉眼所見の赤い斑点に 相当する，茸状の乳頭の中心部には，味蕾の開口部，す なわら味孔も認められる（写真 4, 5). 苜状の乳頭む， 舌尖部付近においては形態がやや小さい、しかし，舌尖 部では数が多い

舌背の隆起部においては，舌前 $1 / 3$ 部ならびに舌中 1/3 部における糸状の乳頭とは著しく異なり，大きな花 弁状 (many-petal-shaped) の乳頭が認められる（写直 6，7). その乳頭の尖端は，隆起部の中央部では上方に, 隆起部の前方部では前方に，側方部では側方に，後方部 では後方に向いており，舌隆起部の中央部より放射状 (radiated) に乳頭の尖端が向いている配列を示してい る. 乳頭間粘膜上皮は認められない

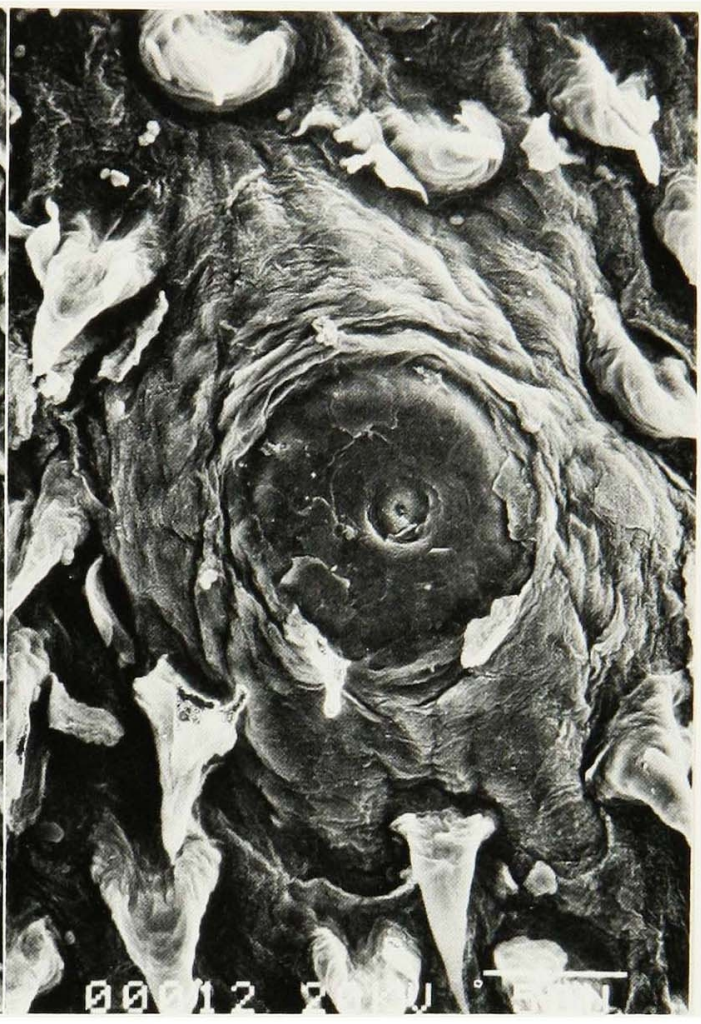

写真 5 八ムスター舌背の走查電顕所見

写真 4 の一部拻大. 米状乳頭は, 乳頭尖端を後方に 向けた，いわゆる円鐎状を呈しているが，孚頭の両 側縁は，前内側（写真では上の方が舌尖側である） にまくれ込んだような構造になって扣り，その結 果, 系状乳頭の前面は，桶状あるいは移植鏝（いし ょくごて) 状にみ光る。茸状乳頭のほぼ中央には，

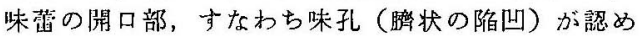
られる。

舌後 $1 / 3$ 部においては, 舌前 $1 / 3$ 部ならびに舌中 $1 / 3$ 部に括ける系状の乳頭とは異なり，棘状 (spine-shaped) で，大きな形態を呈している（写真 8，9）。乳頭間粘膜 上皮は認められない，乳頭の尖端は後方ないし後内方に 向いている．舌後 $1 / 3$ 部においては苗状の乳頭は認めら れない、ただし，舌後 $1 / 3$ 部に拈いても，前側方部分に おいては, 舌中 $1 / 3$ 部におけると同様の系状の乳頭が認 められまた柴状の乳頭も散在している.

喉頭蓋の $2 \sim 3 \mathrm{~mm}$ 前方 (rostral) に位㯰している 1 個の棈円形の乳頭は，その前方側を除いて周囲が深い清 (trench, deep furrow) でとり囲まれている (写真 9 ). この乳頭付近の系状乳頭は，この乳頭をとり囲さかのよ らに，その尖端の方向を後内方に向けている.

岏頭蓋とこの大きな 1 個の乳頭との間の約 $2 \mathrm{~mm}$ 幅の 部分には，糸状乳頭は認められず，舌背粘膜は病状に， 


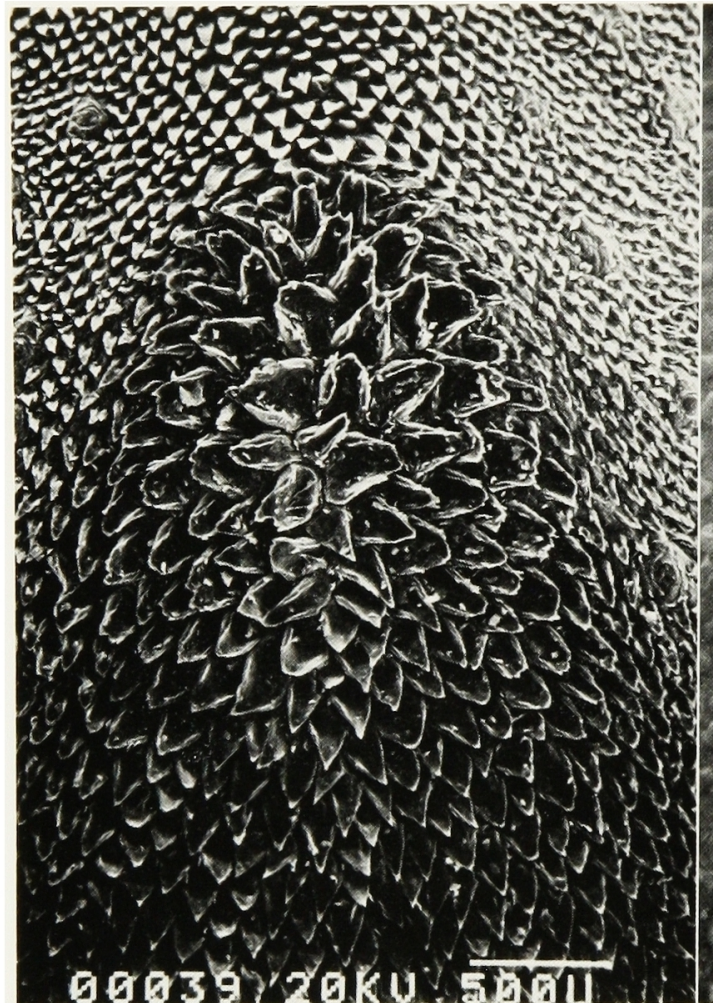

写真 6 ハム人タ一舌背の走査電䫓所見 舌隆起部付近。舌隆起部の乳頭は，著しく大きい。 羿頭尖端は放射状に種々の方向に向いている。すな わち，舌隆起中央部では上方に，側方部では側方 に, 後方部では後方に向いて盚り, 合花弁状の花ひ らあるいは松球（まつかさ）状にみえる。舌隆起 部の後縁は，明らかな境界なしに舌後 $1 / 3$ 部の禾状 乳頭に移行している

もり上がっている.

舌根部雨側緣に，平行に並んた 7 10個の畧状の静造 よりなる乳頭が認められる(写真10)。平行に並んだ乳頭 の前方部は，次第に形態が小さなって舌侧縁の系状乳 頭に移行する。乳頭間の溝は深い。

\section{総括ならびに考察}

八ムスターの口腔粘膜に関する形態学的研究の報告 は，頓裂を除けばはとんどない，また，実験動物の解剖

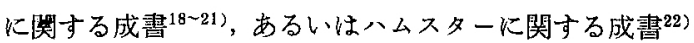
です，口腔に関しては歯式その他の簡単な記載があるの みであり，口腔粘膜の揹造や解剖名に関して詳細を知る ことはできない.

扎そらく，ハムスターが実駼動物として使用されはじ

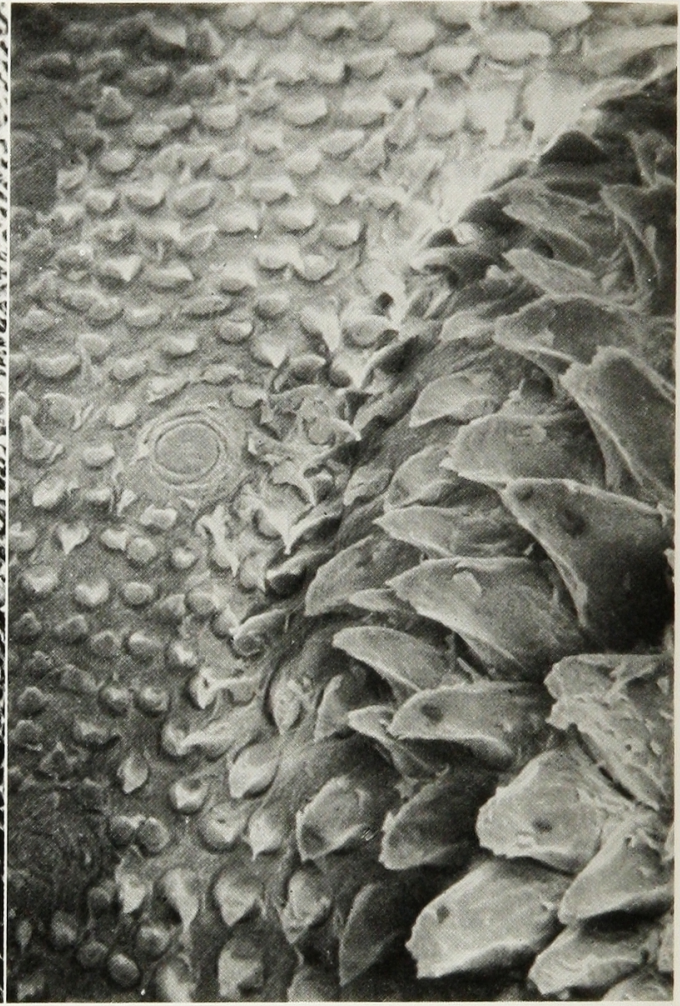

写真 7 ハムスター舌背の走査電顕所見 写真 6 の一部拡大．舌隆起部の禾状孚頭とそれより 前方ないし前外方の系状乳頭とでは，大きさ・形熊 ・配列に著しい差異が認められる。

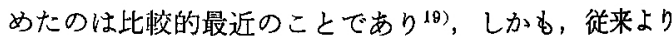
口踛粘膜の研究にはウサギ・ラット・マウスが多く使用 され，頓整といら特殊な部位を除けば，特に実験動物と してハムスターを使用したほらが有利である根扰すなか ったのが，その理的ではないかと思われる。

しかし，口腔粘膜癌の研究に関する限り，ハムスター

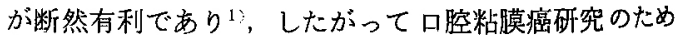
の基碟資料とするため，正常ハムスター口腔粘膜の基磰 的研究が必須である。

今回は，八ムスター正常舌背部の走查電顕的研究 ${ }^{16)}$ 報告するにさきたち，ラット・マウスなどのげっ崡目 (order: Rodentia)に関寸る椧文 ${ }^{2325)}$ や成書 ${ }^{18,26 ~ 29), ~ さ ~}$ らに济っ因目に近い我形目・ウサギ科（order：Lagc-

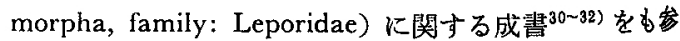
誟にして，八ムスタ一の舌背，特に舌乳頭の解剖名に関 


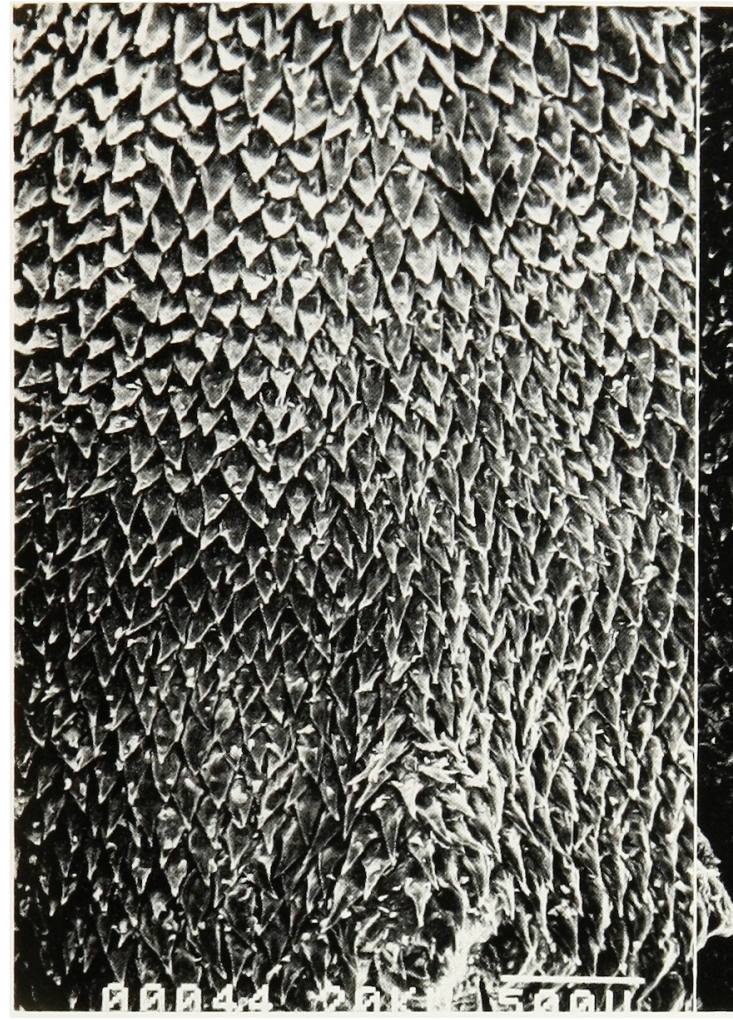

写真 8 八ムスタ一舌背の走查䉓頙所見

舌後 $1 / 3$ 部で, 舌隆起部より後方部付近. 话前 $1 / 3$ 部 ならび长舌中 $1 / 3$ 部に打ける釆状乳頭上りは大き く，乳頭尖端を後方に向け，粦状を呈している。乳 頭間粘膜上皮は認められない，茸状乳頭は認められ ない.

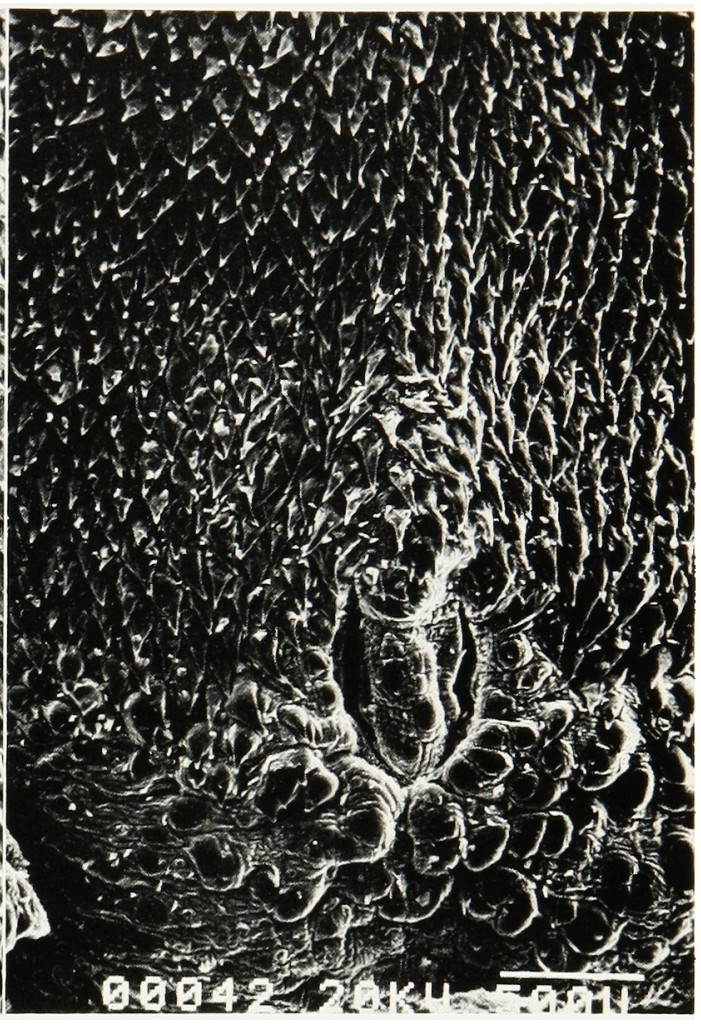

写真 9 ハムスタ一舌背の造查電顕所見

舌後 $1 / 3$ 部で, 舌後端部付近. 前方㑡を除いて周国 を深い瑇で囲まれた 1 佩の有郭乳頭が認められる。 有郭乳頭より後方部においては系状乳頭は認められ ず，粘膜は疣状に隆起している
してわれわれの見解を述べたいと考える。

マウス・ラット・ハムスターの解剖に差はないとする

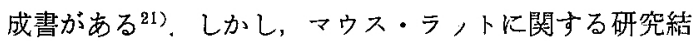
果をそのままハムスターにあてはめることに，疑問があ るように思われる。

表 1 こごく，これらの央験動物の生物学的分類位咱: は、げっ電目に分類される点には異論がないが、マウ ス・ラットはネズミ科 (family: Muridae)に分類される のに対し，八ムスターはキヌネズミ西科 (subfamily: Cricetinae）に分類されたり，また，ネズミ科とは全く 独立のキヌネズミ科 (family: Cricetidae) に分類された りしている19)したがって，八ムスターはマウス・ラッ トと同一の解剖を前提にするにはいささかの牆念をおぼ える、そこで，マウス・ラットに関する研究18,21,23 29)を 参考炕するが，一応，改めて八ムスターの释剖を検討 する必要がある

\section{ハムスター舌背の肉眼所見}

八ムスターの舌は，前後 (rostral-caudal) に長く，歯 隙部 ${ }^{18)}$ (diastema) では幅広いが，臼荬部では丽侧より 圧排されたように幅がやや狭くなっており，さらに目狩 部より後方では，再び幅がやや広くなっている

舌前 $1 / 3$ 部の舌背正中に明らかな溝が認められる。兵 正中溝 (median sulcus, sulcus medianus linguae) 上呼 称したい

舌中 $1 / 3$ 部と舌後 $1 / 3$ 部の筧界付近で, 舌背正中に明 らかな隆起が認められる。舌隆起 (dorsal prominence, prominentia linguae) と呼称したい。この舌隆起は， 明らかな境界なく，次第に舌後 $1 / 3$ 部に䔟行する.

舌隆起部ならびに舌後 $1 / 3$ 部, 特に舌隆起部において は，系状の乳頭を肉腿で観察できる。しかし，舌隆起 より前方部，すなわち舌前 $1 / 3$ 部ならびに舌中 $1 / 3$ 部よ りなる舌前方 $2 / 3$ 部では，斐面が粗粘なのはわかるが， 


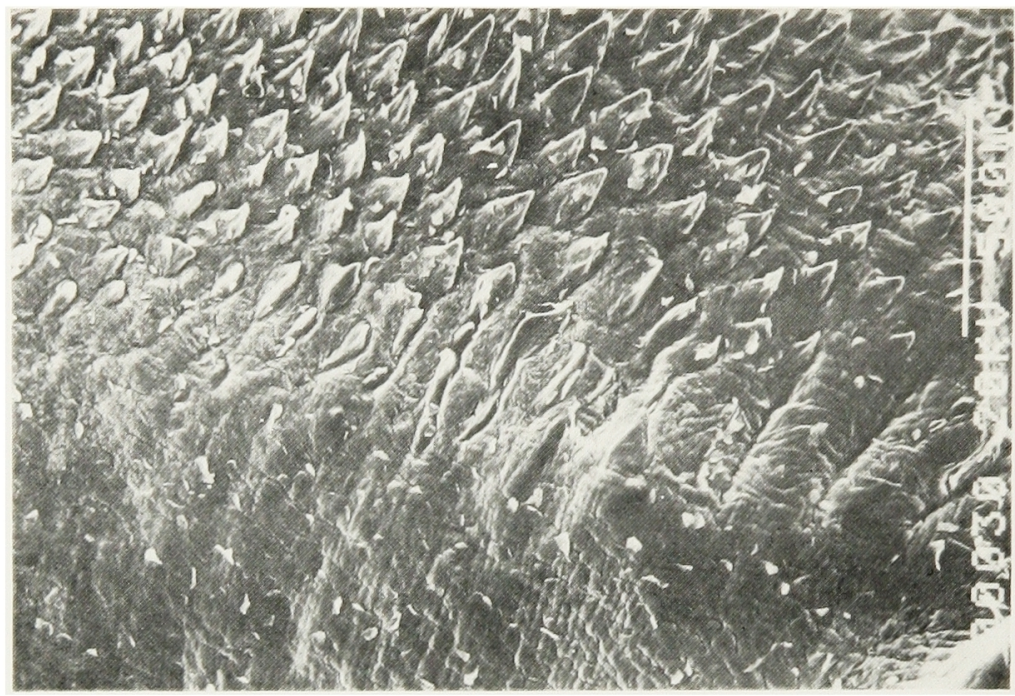

写真 10 八厶スタ一舌背の走查電顕所見

舌後1/3部で, 右後縁部付近. 平行に並んだ嘼状の藮状乳頭が認められる。

表 1 マウヘ・ラット・ハムメターの生物分類学的位監

脊椎動物門 (phylum: Vertebrata)

哺孚網 (class: Mammalia)

げっ菌目 (order: Rodentia)

下ズミ科 (family: Muridae)

ハッカネズミ属 (genus: Mus)

ハッカネズミ種 (species: musculus)

ハツカネズミ Mus musculus

クマネズミ属 (genus: Rattus)

トブネズミ㮔 (species: norvegicus)

ドブネズミ Rattus norvegicus

シロネズミ Rallus norvegicus var. albus ネ゙ミ科 (family: Muridae)

キヌネズミ亜科 (subfamily: Cricetinae)* (genus: Mesocricetus)

(species: auratus)

ヨ゙ールデンハムハター

Mesocricelus auratus

*八ムスターの属する科を Cricetidaeとして独立させ， Muridae とわけている研究者もいる。

文苚19）の内容を著者らが表にまとめた。

肉腿で禾状の乳頭を観察することができない，したがっ て，舌隆起の前縁ならびに侧䌂を賞界線として，系状の 乳頭はその形態の異なっていることが理解できる，後述 のごとく，この境界部に分界線 (terminal line, Linea terminalis）を仮想したい。

なお，喉頭蓋より $2 \sim 3 \mathrm{~mm}$ 前方の舌正中線上に，杵
円形の渋造物が認められる，不対の有郭乳頭である。 た, 舌前方 $2 / 3$ 部ならびに舌後 $1 / 3$ 部の前側方, すなわ ち境界線より前方に散在性に赤い斑点状の搆造物が認め られる。柴状乳頭である。

\section{ハムスター舌背の走查電顕所見}

糸状乳頭 (filiform papilla)

各種動物の舌で，舌背粘膜の大部分を㬓い，最む数が 多く，系状や円锤状にみ文，味蕾を有しない乳頭は，一 般に兼状乳頭（広義）と呼ばれている。動物の種類によ って形態は大きく異なる，たとえば，犬では舌前方 $2 / 3$ 部は系状乳頭 (filiform papilla)（狭義），舌後方 $1 / 3$ 部 は円䤵乳頭 (conical papilla) と呼びわけられたり ${ }^{33)}$, ラットでは舌前方 $2 / 3$ 部は比較的高さの低い系状乳頭で あり，円鉦状にみえることから円鋊乳頭 (conical papilla), 舌後方 $1 / 3$ 部は高さが高く，来状にみえること から真の系状乳頭 (true filiform papilla) と呼びわけら れたりする25).

八ムスターでは，写真 $2 \sim 5$ のごとく，舌隆起より前 方, すなわち舌前方 $2 / 3$ 部においては系状乳頭の尖端は 後方 (caudal) k向いており，いわゆる円䤵状 (coneshaped) を呈する。乳頭間粘膜上皮が認められる.

舌隆起部に扣いては，形態が特に大きく，乳頭尖端の 方向は，舌隆起の中央を中心にして 放射状に向いてお り，また，乳頭間粘膜上皮は認められない，すなわち， 舌前方 $2 / 3$ 部の糸状乳頭とは著しく異なった形態を呈し ている。

舌後 1/3 部に扣いては，系状乳頭の尖端は後方（caudal)に向いて扣り，いわゆる棘状 (spine-shaped) t星 し, 乳頭間粘膜上皮は認められず，舌前方 $2 / 3$ 部の系状 


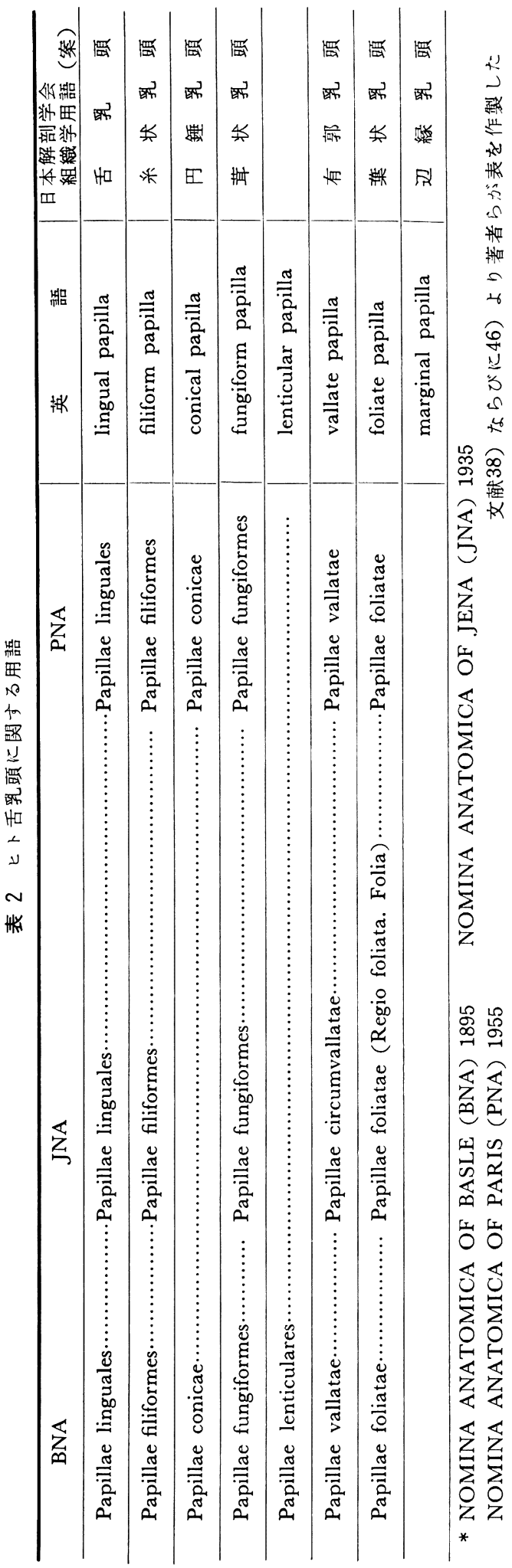

乳頭とは異なった形態を呈している。

これらの異なった形態の乳頭は, それぞれの解剖名で 呼称すべきか否かに対するわれわれの見解は以下のとお りである。

もともと系状乳頭は動物の種類によって形態を異にす る.また, 同一種類の舌でも, 舌の部位によって形態が 異なる。それを動物の種類ごとに，あるいは舌の部位ご とに解剖名をつけるとすれば，解剖名は膨大な数にのぼ り, 用語の混乱の起きることは必至である。したがっ て, やはり多少形態が異なっても, 舌背で最も数が多 く, 味蕾を有しない乳頭を系状乳頭（広義）と呼ぶこと にし，動物の種類や部位によって形態が異なり，特別に 区別して呼称する必要がある際には，適宜，適当な形容 詞をつけるか, または, 舌の部位名をつけて呼ぶのが妥 当ではないかと考える。

以上より，われわれは八ムスターの系状乳頭を，(1) 舌前 $1 / 3$ 部の 系状乳頭, (2) 舌中 $1 / 3$ 部の 系状乳頭,

(3) 舌隆起部の系状乳頭, (4) 舌後 $1 / 3$ 部の糸状乳頭に 大別し，さらに舌隆起部ならびに分界線より前方（rostral）は，形態に差異がないので舌前方 $2 / 3$ 部の系状乳 頭として一括することにしたい.

なお，舌隆起部を境界にして，系状乳頭の形態・大き さ，ならびに系状乳頭尖端の配列の方向が異なるので， この境界部に分界線（terminal line）を仮想するのは妥 当と思われる.

舌隆起部の系状乳頭の形態が大きいことは，ラットや マウスでも知られており, giant conical papilla ${ }^{25)}$, giant filiform papilla ${ }^{29)}$ ，あいは良く発達した系状乳 頭 ${ }^{5}$ 26) などと呼ばれている。しかし，この部の系状乳頭 は，単に形態が大きいばかりでなく，配列の方向にも特 徵があり，乳頭間上皮は認められず，また，微細構造に も特徵があり ${ }^{16)}$, 上記のごとく，巨大 (giant) であると か，よく発達した系状乳頭 $\left.{ }^{5}, 26\right)$ などの呼称は，この部の 乳頭の特徽を表現するには不十分であり，不適当である と思われる. 舌隆起部の系状乳頭と呼ぶ汪らが妥当と考 える。

なお，ラット・マウスに関する成書では，系状乳頭の 尖端は後方に向いているのに対し，舌隆起部の系状乳頭 は前方に向いているとの記載がある ${ }^{26,29)}$. 確かに舌隆起 部の正中前縁部の 系状乳頭は前方に向いている。しか し，側方部では側方に向いており，後方部では後方に向 いており，結論としては舌隆起部の中央を中心として放 射状に花弁状に傾いているので，この記載はハムスタ一 では正しくないおそらく，従来の光顕レベルの断面像 による钼察結果からの記載と思われる.

走査電顕による立体的観察で，この舌隆起部の特徴あ る形態を良く観察することができる。

なお，Kutuzov \& Sicher ${ }^{25)}$ は,ラットの舌隆起 (lingual prominence) の乳頭を giant conical papilla と呼 


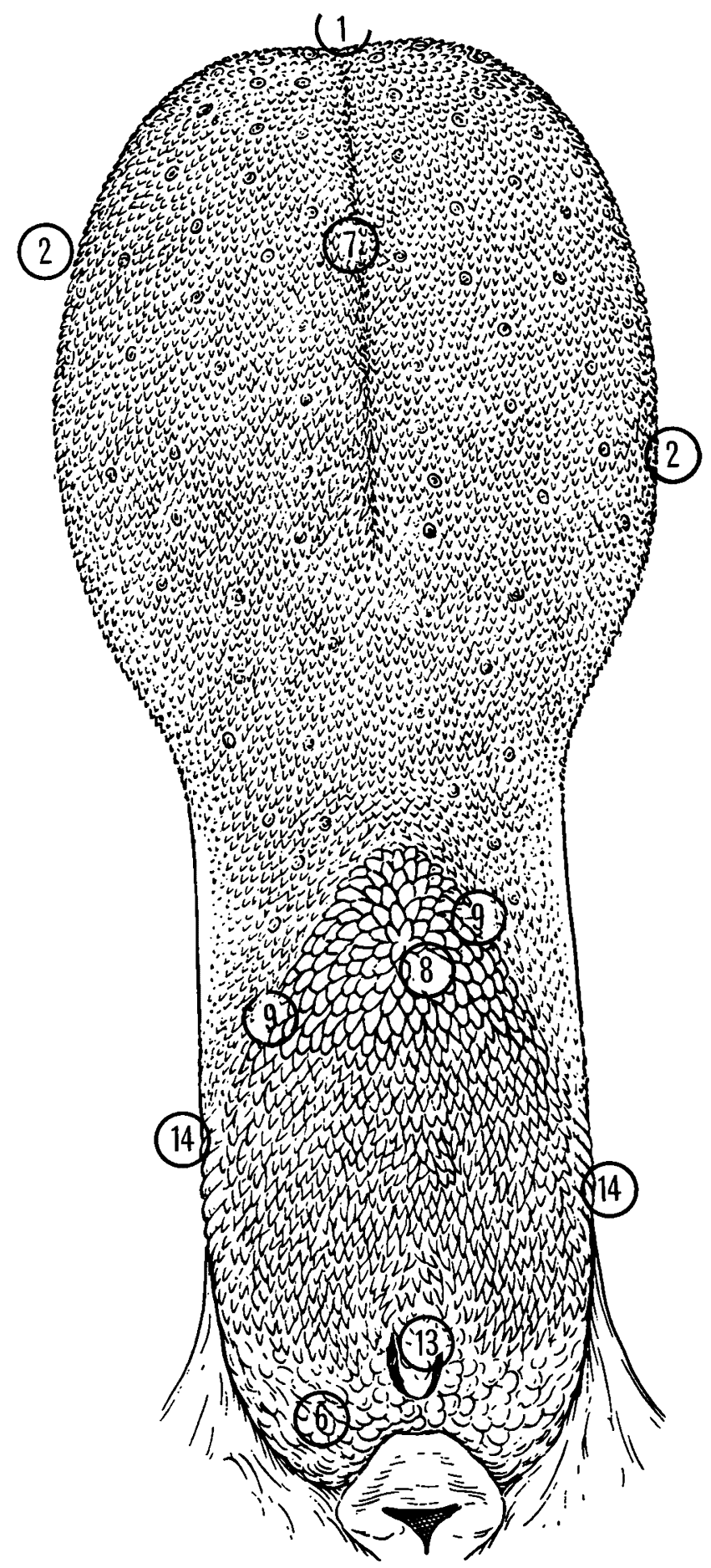

図 1 ハムスター舌背のシェーマ

数字で示した部位に対応する解剖学用語は, 次頁の表 3 の数字に 対応させてある。 
表 3 八ムスタ一舌背の解剖学用語
(1) 舌尖 apex of the tongue
(2) 舌縁 lingual margin
(3) 舌前 $1 / 3$ 部 rostral third of the tongue
(4) 舌中 $1 / 3$ 部 middle third of the tongue
(5) 舌後 $1 / 3$ 部 caudal third of the tongue
(6) 舌後端部の粘膜 mucosa of the caudal end of the tongue
(7) 舌正中渶 median sulcus
(8) 舌隆起 dorsal prominence
(9) 舌分界線 terminal line
(10) 舌乳頭 lingual papilla
(11) 系状乳頭 filiform papilla papilla

(1) 舌前方 $2 / 3$ 部の糸状乳頭 filiform papillae of the rostral two thirds

(i ) 舌前 $1 / 3$ 部の系状乳頭 filiform papillae of the rostral third

(ii) 舌中 $1 / 3$ 部の糸状乳頭 filiform papillae of the middle third

(2) 舌隆起部の糸状乳頭 filiform papillae of the dorsal prominence

(3) 舌後 $1 / 3$ 部の系状乳頭 filiform papillae of the caudal third

(12) 茸状乳頭 fungiform papilla

(13) 有郭乳頭 vallate papilla

(14) 葉状乳頭 foliate papilla

(15) 辺縁乳頭 marginal papilla

前頁のハムスター舌のシェーマに, 解剖学用語に相当する部位を数字で対応させてある

称し, この乳頭尖端は, 舌隆起前縁部では後方に向いて おり，後縁部では前方に向いていると記載し，八ムスタ 一におけるわれわれの観察とは全く異なった配列を記载 しているが，その付図（Fig 2) をみた範囲では，八ムス ターと類似した配列になっているものと思われる。しか し，ラットとハムスターのロ腔粘膜には種々の点に関し て差異のあることも考えられるので, 今後の研究課題と したい。

\section{茸状乳頭 (fungiform papilla)}

系状乳頭より数ははるかに少なく, 舌隆起部ならびに 分界線 (terminal line) より前方 (rostral) に散在してい る. 系状乳頭より大きく, 表面はやや平滑で, 味蕾を有 している，短く，やや細い茥を有し，茸状を呈する構造 にその名称の由来がある ${ }^{37}$. 解剖名に関しては, 比較解 剖学的に何ら問題なく茸状乳頭の名称を用いてさしつか えないと思われる。なお，舌前 $1 / 3$ 部，特に舌尖部にお ける茸状乳頭よりも舌中 $1 / 3$ 部における荈状乳頭のほ が，やや大きな形態を示している.

有郭乳頭 (vallate papilla)

内外の医学辞典や解剖学用語の解説では, vallate papilla \& circumvallate papilla も同義語とされ ${ }^{34)}$, 日本 語訳は有郭乳頭，輪状乳頭あるいは輪廓乳頭 $\left.{ }^{35}, 37\right)$ であ り，周囲に壁 (wall, vallum) をめぐらされた，あるい は堤防で囲まれたような棈造にその名称の由来があ
$ろ^{37)}$.

ヒトの有郭乳頭は，BNA（1895）では papillae vallatae であったが, JNA (1935) で papillae circumvallatae となり, PNA (1955) で再び papillae vallatae と呼ばれて現在に至っている ${ }^{38}$ (表 2 ). したがって, こ れに相当する英語は， vallate papilla が適当と思われ る.

八ムスターの舌において, 啹頭蓋の $2 \sim 3 \mathrm{~mm}$ 前方 (rostral) に位置する不対の大きな乳頭は, 比較解剖学 的にヒトの有郭乳頭と相同 (analogous) である ${ }^{39 \sim 41)}$. そうならば, Hebel \& Stromberg ${ }^{26)}$ も使用しているごと く,この乳頭もヒトの有郭乳頭に準じて vallate papilla と呼ぶのが妥当ではないかと考えられるので, われわれ の今後の論文では, 有郭乳頭（vallate papilla）とした い.

ちなみに，有廓乳頭 35 37) ではなく，有晫乳頭と“郭” を用いる。

葉状乳頭 (foliate papilla)

ヒト・ウサギ・ラットなどと同様に，八ムスターでも 舌根部雨側縁に葉状乳頭が位置している. $7 〜 10$ 個の乳 頭が畧状に平行に並んでおり，その前方部は次第に形態 が小さくなって系状乳頭に移行する. 乳頭間の清は深 い, 解剖名に関しては, 比較解剖学的に何ら問題なく葉 状乳頭の名称を用いてさしつかえないと思われる ${ }^{39 \sim 41)}$. 
辺縁乳頭 (marginal papilla)

この乳頭は, Orban の口腔組織・発生学 ${ }^{42)}$ や Bloom \& Faucett の組織学 ${ }^{43)}$, 上條の口腔解剖学 ${ }^{44)}$ をはじめ とする内外の代表的成書にも記載がなく, 代表的医学辞

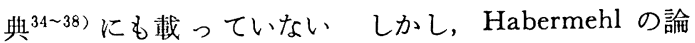
文 ${ }^{45)}$ や Miller の犬の解剖学 ${ }^{33)}$ に記載があり, 最近で は, 日本解剖学会組織学用語 (案) ${ }^{46)}$ にもその名称が記 載されている。

哺乳類に打いて, 哺乳時期に一致して一時的に認めら れる乳頭で，吸綴のために閉鎖を完全にして陰王を作り やすくするために舌の辺縁に出現すると考えられてい る ${ }^{33)}$. おそらく，哺乳類の舌には広く認められるものと 考えられる ${ }^{47)}$. 最近, Yamasaki \& Takahashi ${ }^{47)}$ は, ヒ トの乳児の舌で辺縁乳頭を確認している．しかし，ハム スターやラットでは，いまた確認されていない，今回の 試料はすべて生後 5 週路以上のハムスターであり,すで に固型飼料を摂取しており, 辺縁乳頭は確認できなかっ た。

以上のごとく，八ムスターの舌背を肉眼的, 光顕的, 走查電顕的に観察し, 得られた钼察結果を総括して, 図 1 のごときハムスターの舌のシェーマを作製した。 ま た，今後の研究に必要なハムスター舌の解剖名に関する われわれの見解を表了にまとめた。

なお，八ムスター舌背の光顕所見ならびに走査電顕所 見による微細構造に関しては，稿を改めて報告する ${ }^{16)}$.

結語

ハムスター口腔粘膜の形態に関する詳細な研究はほと んどなく，部位によっては解剖名が明確に決められてい ない.

われわれは, 八厶スタ一舌背部における舌癌形成過程 の走査電顕的研究の基礎資料とするために, 正常ハムス ターの舌背を走查電顕的に観察し，興味ある所見を得 た.

八ムスター舌背の解剖名に関して，われわれの見解を 述べ，今後の研究に必要な解剖名に関して，われわれの 見解をまとめた。

風篗するに際し，資料収集にご協力いただき，また， 貴重なこ教示，こ助言をいたたきました札幌医科大学第 1 解剖高橋杏三教授, 同進学課程生物学山崎英雄教授, 北里大学医学部実臨動物学中野健司教授, 九州檤科大学 第 2 口腔解剖西䍀; 邦昭熘師に感謝の意を表します。

またここ校閲いただき米した東日本学園大学㦀学部口 腔病理奥山富三教授に感暗の意を表します。

なお，本論文の项旨の一部は，第36回日本口腔科学会 総会（昭和 57 年 5 月 $13 \sim 15$ 日，名古屋）に打いて発表
した。

\section{引用 文 献}

1）佐々木元賢，藤田浄秀，他：口腔粘膜癌の实験 的形成と hamster. 医学のあゆみ 88：557 1974.

2) 藤田浄秀, 賀来 亨, 他：舌癌の実験的形成に 関する研究第 1 編 9,10-dimethyl-1,2-benzanthracene の塗布による舌癌の実験的形成. 口科誌 21: 9991972.

3) Fujita, K., Kaku, T., et al.: Experimental production of lingual carcinomas in hamsters by local application of 9,10-dimethyl-1,2benzanthracene. J dent Res 52: 3271973.

4) Fujita, K., Kaku, T., et al.: Experimental production of lingual carcinomas in hamsters: Tumor characteristics and site of formation. J dent Res 52: 11761973.

5）藤田浄秀, 賀来 亨, 他：舌瘦の実験的形成に 関する研究第 7 編 舌背部に打ける舌癌形成 過程の組織学的研究。口科誌 22：550 1973.

6) 賀来 亨, 藤田浄秀, 他: 舌癌の実驗的形成に 関する研究第12編 舌背部に扣ける発癌剈の 単純塗布による舌瘦形成過程の組織学的研究。 日口外誌 24：33 1978.

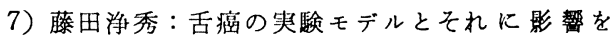
扰よほ諸因子について。橫浜医学 32: 193 1981.

8）賀来㧸, 藤田浄秀, 他: 9, 10-dimethyl-1,2benzanthracene の䤰布による口蓋粘膜癌の実 験的形成。日口外誌 19:435 1973.

9）小田島哲世, 垍 元徳, 他 : 口蓋粘膜癌形成過 程の組織学的研究. 日口外誌 22: 4461976.

10）藤田浄秀, 賀来 亨, 他：9,10-dimethyl-1, 2-benzanthracene の塗布による米肉癌の実験 的形成. 日外誌 19:266 1973.

11）藤田浄秀, 大村 進, 他 : 実験的菌肉癌形成過 程の組織学的砳究. 日口外誌 27：1557 1981.

12) 大村進, 藤田浄秀, 他 : 実臨的ハムスタ一舌 癌形成過程の走查電頟的矿究 第 1 編 舌側綝 中 $1 / 3$ 部に打ける舌痛形成過程。日口外誌 28 (5): 1982 印刷中.

13）大村進，藤田浄秀，他：実験的八ムスタ一舌 瘦形成過程の走査電顕的研究 第 2 編 舌背部 に打ける舌癌形成過程。日口外誌投稿予定

14）铃木信治, 大村進，他：幽肉痛形成過程の走 查電影的研究 第 1 編 八厶スタ一下顎展側药 肉部に扮ける透肉痛形成過程。日口外誌 28 : 1982 印刷中.

15) 大村進, 藤田浮秀, 他 : 口蓋粘膜癌形成過程 の走查電顕的研究第 1 編 八厶スタ一実臨的 口蓋粘膜癌の形成過程。日口外誌投稿予定.

16) 大村進, 藤田浄秀, 他 : 八厶スタ一口膑粘膜 の走查電顕的研究 第 1 編 舌背部の走查電顥 
的峴察。米基礎誌投稿予定。

17）鈴木信治, 藤田浄秀, 他：八ムスター口腔粘膜 の走查電顕的研究 第 2 編 口蓋部の走査電顕 的钼察。荘基整誌投稿予定.

18）嶋井和世, 西村陽三(訳)：カラーフトラ人 ガ イドブック ラットの解剖。広川苦店, 東京, 1980.

Olds, R.J., Olds, J.R.: A colour atlas of the rat-Dissection guide. Wolfe Medical Publications LTD, London, 1979.

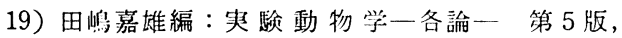
朝食借店, 東京, 1975.

20) Ribelin, W. E., McCoy, J. R. (ed): The pathology of laboratory animals. Charls C Thomas, Illinois, 1971.

21）伊東信行：実験用小動物組織学一ラット，マウ ス，八ムスタ一。新宿書房, 東京, 1974.

22) Humburger, F. (ed): Pathology of the Syrian hamster. Prog exp Tumor Res Vol 16, Steiner \& Co, Basel, 1972.

23) Fish, H.S., Malone, P.D., et al.: The anatomy of the tongue of the domestic Norway rat. I. The skin of the tongue; the various papillae; their number and distribution. Anat Rec 89: 4291944.

24) Fish, H.S., Richter, C.P.: Comparative numbers of fungiform and foliate papillae on tongues of domestic and wild Norway rat. Proc Soc Exp Biol Med 63: 3521946.

25) Kutuzov, H., Sicher, H.: The filiform and the conical papilla of the tongue in the white rat. Anat Rec 110: 2751951.

26) Hebel, R., Stromberg, M.W.: Anatomy of the laboratory rat. The Williams \& Wilkins Co, Baltimore, 1976.

27) Smith, E.M., Calhoun, M.L.. The microscopic anatomy of the white rat. ed 1, The Iowa State University Press, Iowa, 1968.

28) Kessel, R.G., Kardon, R.H.: Tissue and Organs: A text-atlas of scanning electron microscope. W.H. Freeman and Company, San Francisco, 1979, p 153.

29) Green, E.L. (ed): Biology of the laboratory mouse. McGraw-Hill Book Co, The Blakiston Division, New York, Toronto, Sydney, London, 1966, p 272.

30）津崎孝道: 夹駼洏物解剖学第 1 巻鬼. 金原 出版, 東京, 京都, 1963 .
31) McLaughlin, Ch. A.: Laboratory anatomy of the rabbit. WM C Brown Co, Iowa, 1970.

32) 板垣 博, 大食永治, 他編(訳)：夷䮖用ウサギ の生物学。文永堂, 東京, 1978 .

Weisbroth, S.H., Flatt, R.E., et al. (ed): The biology of the laboratory rabbit. Academic Press INC (London), New York, San Francisco, London, 1974.

33) Evans, H.E., Christensen, G.C.: Miller's Anatomy of the dog. ed 2, WB Saunders Co, Philadelphia, London, Toronto, 1979.

34) Friel, J.P. (ed): Dorland's illustrated medical dictionary. ed 25, WB Saunders, Philadelphia, London, Toronto, 1974.

35）加滕勝治編：医学英和大辞典 Kato's integrated English-Japanese medical dictionary. 南山堂, 東京, 1960.

36）大矢金節著：英和医学辞典。金原出版, 1963.

37) 吉汹修一郎, 栗屋和彦: 解剖学用語とその解 説. 医学者院, 1968.

38) Donath, T.: Anatomical Dictionary (English edition edited by Crawford, G.N.C.). Pergamon Press, Oxford London Edinburgh, New York, Sydney, Paris, Braunschweig, 1969.

39) Zietzschmann, O., Ackerknecht, E., et al. (bearbeitet): Ellenberger-Baum-Handbuch der Vergleichenden Anatomie der Haustiere. Aufl 18, Springer-Verlag, Berlin, 1943, Seite 362.

40）徍田金次郎：舌の研究（I）。自然 20(4)：64 1965.

41）蕉田金次郎：舌の研究（II）。自然 20(5)：40 1965.

42) Bloom, W., Fawcett, Don W.: A textbook of histology. WB Saunders, Philadelphia, 1970.

43) Bhaskar, S.N. (ed): Orban's Oral histology and embryology. ed 8, The CV Mosby Co, Saint Louis, 1976.

44）上條雍彦：口腔解剖学. 第 3 版, アナトーム 社, 東京, 1970 .

45) Habermehl, K.H.: Über besondere Randpapillen an der Zunge neugeborener Säugetiere. Z Anat Ent Gesch 116: 3551952.

46) 山田英智, 尾持昌次, 他: 組織学用語（案）に ついて。解剖誌 56：462 1981 .

47) Yamasaki, F., Takahashi, K.: Personal communication. 